\title{
Pengembangan Modul Biologi Berbasis Problem Based Learning Siswa SMK Pertanian pada Materi Pewarisan Sifat
}

\author{
Adelima Dyah Kartika $^{1}$, Siti Zubaidah ${ }^{1}$, Heru Kuswantoro ${ }^{1}$ \\ ${ }^{1}$ Pendidikan Biologi-Universitas Negeri Malang
}

\begin{tabular}{l}
\hline \hline INFO ARTIKEL \\
\hline Riwayat Artikel: \\
Diterima: $26-06-2019$ \\
Disetujui: $23-06-2020$ \\
\hline
\end{tabular}

\section{Kata kunci:}

problem based learning;

inheritance;

SMK students;

problem based learning;

pewarisan sifat;

siswa SMK

\begin{abstract}
ABSTRAK
Abstract: The aim of this research and development was to examine the validity and practicality of problem based learning biology modules for High School students at Tulungagung. Based on the results of research on heterosis F1 soybean characterization resulting from crossing argomulyo varieties and CpMMV resistant lines. The learning module development model used is the ADDIE by Welty. The module feasibility assessment is assessed by namely practitioners, material experts and teaching materials experts, who are competent in their fields. Practical test through testing a small group of students using the questionnaire given. Overall, the results of module validation developed by material expert validators, module experts, and field practitioners in accordance with the aspects assessed and practicality tests obtain a good percentage, so that it can be concluded that the development of PBL-based modules on inheritance properties is stated very practical.
\end{abstract}

\begin{abstract}
Abstrak: Penelitian pengembangan ini bertujuan menguji kevalidan dan kepraktisan modul Biologi problem based learning siswa SMKN 1 Tulungagung. Berdasarkan hasil penelitian karakterisasi heterosis F1 kedelai hasil persilangan varietas argomulyo dan galur tahan CpMMV. Pembelajaran menggunakan modul dengan model ADDIE yang dikembangkan oleh Welty. Modul yang dikembangkan dinilai kelayakannya oleh validator ahli materi, ahli modul, dan praktisi lapangan yang sudah kompeten di bidangnya. Uji kepraktisan melalui uji kelompok kecil siswa menggunakan angket yang diberikan. Secara keseluruhan, hasil validasi modul yang dikembangkan oleh praktisi lapangan, ahli modul, dan materi sesuai dengan aspek yang telah dinilai serta dan uji kepraktisan memperoleh persentase yang baik sehingga kesimpulan yang diperoleh pengembangan modul Problem Based Learning Pewarisan Sifat dinyatakan sangat valid dan sangat praktis.
\end{abstract}

\section{Alamat Korespondensi:}

Adelima Dyah Kartika

Pendidikan Biologi

Universitas Negeri Malang

Jalan Semarang 5 Malang

E-mail: dyahkartika271@gmail.com
Berbagai jenis bahan ajar untuk mendukung kegiatan pembelajaran sangat beragam salah satunya terdapat buku (Sadjati, 2004); Hernawan, Permasih, \& Dewi, 2008 ; Lestari, 2013), modul (Sadjati, 2004 ; Hernawan, Permasih, \& Dewi, 2008 ; Lestari, 2013), LKS (Lestari, 2013), dan handout (Sadjati, 2004; Hernawan, Permasih, \& Dewi, 2008) . Masing-masing jenis bahan ajar tersebut memiliki karakteristik yang dapat menunjang proses pembelajaran. Pengembangan modul saat ini dalam proses pembelajaran dibutuhkan sebab memiliki karakteristik unik ( Hernawan, Permasih, \& Dewi, 2008 ; Pranata \& Mahanal, 2016). Bahan ajar cetak berupa modul disusun utuh dan sistematis, terintegrasi dengan pengalaman belajar yang terkonsep dan didesain memudahkan siswa mencapai tujuan belajar (Direktorat Tenaga Kependidikan, 2008; Depdiknas, 2008). Kehadiran modul memudahkan pembelajaran guna menciptakan pembelajaran yang berkualitas dan siswa mampu mempelajari tujuan pembelajaran secara runtut sehingga mampu menguasai semua kompetensi dengan terpadu dan utuh (Eriyadi, 2008; Agustina, Muhdhar, \& Amin, 2014). Modul memuat komponen materi, metode, bahasan dan mengevaluasi disusun secara sistematis dan menarik berfungsi mewujudkan kompetensi sesuai kompleksinya serta memiliki kelebihan sebagai bahan ajar yang lengkap, mudah dibawa, dan dipelajari kapan saja secara mandiri oleh peserta didik (Makmun, 2005 ; Majid, 2007; Direktorat Tenaga Kependidikan, 2008; Depdiknas, 2008). Hal ini tepat untuk mengatasi alokasi waktu yang terbatas ( Depdiknas, 2008; Susanti, 2015). Modul yang dikembangkan akan diterapkan dalam pembelajaran Problem Based Learning. 
Problem Based Learning merupakan model pembelajaran yang menyuguhkan berbagai situasi bermasalah secara autentik dan bermakna kepada siswa, dan dapat berfungsi sebagai batu loncatan untuk investigasi serta penyelidikan (Arends, 2008), guna menemukan solusi dari permasalahan yang telah dianalisis dan dievaluasi (Krisanti \& Mulia, 2016). Karakteristik Problem Based Learning mengacu kepada aliran pendidikan konstruktivisme, dimana belajar merupakan proses aktif dari pebelajar untuk membangun pengetahuannya (Kusumaningtias, Zubaidah, \& Indriwati, 2013). Sintaks dari problem based learning digunakan sebagai pedoman dalam mengarahkan kegiatan belajar siswa dan mendorong siswa untuk terlibat aktif dalam proses belajar serta mengonstruk pengetahuannnya sendiri (Yuan, Kunaviktikul, Klunklin, \& Williams, 2008). Siswa di lingkungan Problem Based Learning lebih setuju pada asumsi konstruktivis pembelajaran kooperatif dan penggunaan masalah otentik karena dapat meningkatkan motivasi belajar (Loyens \& Paas, 2011). Alasan penggunaan model pembelajaran problem based learning karena kondisi pembelajarannya menempatkan situasi dunia nyata dengan jelas dan kontekstual ke dalam kelas melalui pemberian masalah nyata, permasalahan tersebut memberikan informasi, arahan, dan penjelasan pada siswa sewaktu mereka membangun pengetahuan baru selain mengembangkan kecakapan menyelesaikan masalah (Mayo, P., Donnelly, M.B., Nash, P. P. \& Schwartz, R.W, 1993). Pembelajaran menggunakan PBL dimulai dengan memberikan suatu permasalahan nyata yang wajib diselesaikan siswa (Boud, 1985; Boud \& Feletti, 1991). Masalah nyata dan kompleks yang diberikan akan memicu serta memotivasi siswa untuk mengidentifikasi, mempelajari konsep/prinsip yang diperlukan agar dapat menyelesaikan masalah (Duch, B.J., Allen, D.E. \& White, H.B, 1998 ; Belt, S., Evans, E., McCreedy, T., Overton,T. \& Summerfield, S., 2002.) Pembelajaran menggunakan modul biologi berbasis PBL berpotensi mewujudkan kegiatan belajar mandiri (Primarinda, I., Prayitono, A, B., \& Maridi, 2015). Pengalaman belajar menggunakan modul biologi dengan Problem Based Learning meningkatkan keterampilan berpikir dan membangun pikiran efektif dalam penyelesaian masalah (Whitcombe, 2015). Selain itu, pembelajaran menggunakan modul berbasis Problem Based Learning membantu memberikan informasi pada siswa yang jelas dan sistematis, sehingga dapat dijadikan sumber belajar mandiri yang mampu menampilkan kompetensi terhadap sikap ilmiah, kreativitas, pikiran logis, dan produktivitas (Alfiantara, Kusumo, \& Susilaningsih, 2016).

Hasil wawancara dengan guru pengampu mata pelajaran Biologi di SMKN 1 Tulungagung hari Rabu 22 November 2018 bahwa kebutuhan kegiatan pembelajaran sudah cukup mendukung, karena untuk kegiatan praktikum siswa disediakan lahan khusus untuk berlatih membudidayakan tanaman. Guru dalam kegiatan pembelajaran menggunakan bahan ajar seperti buku paket, media slide PPT, dan modul. Siswa masih merasa kesulitan memahami materi dan motivasi rendah karena bahasan yang terdapat dalam buku paket lebih banyak berisikan kajian teori serta gambar yang ditampilkan jarang bewarna. Bahasan materi di buku paket belum membahas secara mendetail. Modul yang disajikan guru dalam pembelajaran masih terbatas dengan soal evaluasi dan sedikit materi serta belum menarik perhatian siswa untuk belajar. Penyusunan bahan ajar seperti modul masih terdapat kekurangan dan ketidaksesuaian dengan standar ketentuan dari pemerintah, sehingga menanggapi fakta tersebut perlu dilakukan perbaikan modul yang sesuai dengan kriteria modul yang baik.

Analisis kebutuhan 32 orang siswa kelas ATPH 3 SMKN 1 Tulungagung pada 22 November 2018 menggunakan angket kebutuhan siswa. Hasil perhitungan analisis kebutuhan sebesar 29,08\% menunjukkan guru memberi fasilitas untuk belajar berupa file pdf yang berisikan uraian materi dan belum bersifat kontekstual. Pembelajaran menggunakan modul menunjukkan sebesar $19,47 \%$ jarang dilakukan karena guru sering dalam pembelajaran menggunakan buku paket yang menyajikan materi cukup kompleks dan jarang ada penjelasan gambar. Pembelajaran Biologi dengan memanfaatkan browsing dan laptop untuk tersambung dengan internet menunjukkan sebesar 15,38\%, sehingga mereka dapat mengakses materi pelajaran.

Biologi adalah satu matapelajaran pokok di jurusan agribisnis pertanian. Kenyataannya penerapan pelajaran Biologi siswa kelas X di SMKN 1 Tulungagung membosankan, dianggap sulit dan banyak materi yang harus dihafal sehingga menyulitkan siswa, khusunya materi pewarisan sifat. Hasil wawancara dengan guru menunjukkan materi tersebut membutuhkan konsep jelas dan sulit mengaplikasikan dalam kehidupan nyata. Siswa merasa kesulitan untuk mempelajari adanya hitungan matematis dan konsep abstrak. Materi pewarisan sifat menuntut siswa untuk mengidentifikasi dan menyimpulkan keterkaitan antara gen, DNA, dan kromosom pada pewarisan sifat, sehingga membutuhkan proses belajar yang konteksual dan siswa terlibat dalam menemukan dan memperoleh pengalaman belajar yang bermakna. Harapan guru melalui pengembangan modul Biologi dapat memenuhi tuntutan kompetensi siswa.

Pengembangan modul Biologi Problem Based Learning di dalam proses pembelajaran mencakup hasil penelitian tentang karakterisasi heterosis F1 bibit unggul kedelai tahan virus CpMMV siswa kelas X di SMKN 1 Tulungagung. Berdasarkan kajian peneliti terdahulu menunjukkan bahwa pembelajaran menggunakan modul berbasis Problem Based Learning terbukti dapat mengoptimalkan hasil belajar siswa. Hal ini disebabkan pembelajaran dengan modul berbasis Problem Based Learning, membantu siswa memperoleh pengetahuannya sendiri, menemukan, dan menganalisis masalah, sehingga siswa mampu akan konsep yang dipelajari. Berdasarkan uraian diatas, maka pengembangan modul Problem Based Learning berdasarkan karakterisasi heterosis dengan objek yang diteliti menggunakan tanaman kedelai untuk kegiatan pembelajaran di SMKN1 Tulungagung. 


\section{METODE}

ADDIE merupakan model yang digunakan dalam mengembangkan modul dan terdiri atas tahapan Analysis (analisis), Design (desain), Development (pengembangan), Implementation (implementasi), dan Evaluation (evaluasi) (Welty, 2007 ; Branch, 2009). Model pengembangan ADDIE memiliki kelebihan yaitu tahapannya sistematis, ringkas, dan efisien dalam mengembangkan produk.

\section{Prosedur Penelitian dan Pengembangan}

Tahap analisis (analyze) dilakukan guna mengetahui kebutuhan siswa mengenai bahan ajar pada kegiatan pembelajaran. Akhir dari tahapan ini adalah penentuan judul modul pembelajaran yang akan dikembangkan. Tahap perancangan (design) digunakan untuk menemukan permasalahan yang diperlukan oleh siswa kelas X ATPH 3 di SMKN 1 Tulungagung dalam meningkatkan kualitas pembelajaran dan efektif mencapai tujuan pembelajan. Modul yang dikembangkan akan memuat komponen bagian pendahuluan, isi, dan penutup. Bagian pendahuluan memuat cover, judul modul, kata pengantar, daftar isi, tabel, gambar, petunjuk penggunaan modul, dan peta konsep. Bagian isi memuat kompetensi dasar, tujuan pembelajaran, pendahuluan materi setiap topik, penugasan berupa aktivitas siswa, rangkuman, kunci jawaban, soal evaluasi dan penilaian. Bagian penutup memuat daftar pustaka dan biodata penulis. Produk pengembangan modul berbasis Problem Based Learning pada mata pelajaran Biologi diharapkan dapat bermanfaat untuk seluruh siswa SMK pada topik Pewarisan Sifat.

Tahap pengembangan (develop) bertujuan mengembangkan rancangan yang dibuat menjadi sebuah produk dan dilakukan proses validasi. Tahap ini bertujuan untuk memilih dan membuat materi pendukung produk yang dikembangkan, seperti foto dan gambar hasil penelitian, bahan praktikum, dan materi lain yang mendukung. Media yang dipilih disesuaikan dengan tujuan pembelajaran dan memfasilitasi siswa untuk belajar. Konten yang akan dikembangkan yaitu modul berbasis Problem Based Learning dengan kelima tahapan dari sintaks Problem Based Learning, yaitu orientasi permasalahan, mengorganisasikan proses pembelajaran, membantu investigasi siswa, mengembangkan dan mempresentasikan serta memamerkan, menganalisis dan mengevaluasi proses mengatasi masalah yang disesuaikan dengan rancangan yang disusun pada tahap sebelumnya. Modul yang disusun menggunakan struktur bahasa yang mudah dipahami, memotivasi belajar, dan memuat kegiatan ilmiah. Revisi formatif dilakukan setelah modul pembelajaran yang disusun diuji validasi dengan dosen ahli ahli modul pembelajaran atau bahan ajar, ahli materi dan ahli praktisi/pengguna bahan ajar modul. Pengembangan produk akan dilakukan revisi sesuai penilaian dan mengetahui kelayakan modul. Produk divalidasi menggunakan lembar validasi sesuai kisi-kisi oleh ahli materi, modul, dan praktisi lapangan.

Tahap penerapan (implementation) ini bertujuan untuk menerapkan produk yang telah dikembangkan. Pengembangan ditujukan untuk mendapatkan data kesesuaian produk. Tahap evaluasi (evaluation) dilaksanakan untuk mengetahui kekurangan dari modul. Revisi dilakukan dengan tujuan mengurangi kelemahan kualitas produk yang dikembangkan oleh masing-masing validator. Evaluasi dilakukan untuk memperoleh hasil dari penerapan modul. Hasil yang diperoleh dijadikan dasar untuk menentukan kevalidan dan kepraktisan modul.

\section{Jenis Data}

Data hasil penelitian dan pengembangan berasal dari hasil uji kepraktisan dan validasi ahli. Uji coba pada siswa meliputi uji kepraktisan pada 32 orang siswa. Jenis data yang dihasilkan adalah kuantitatif dan kualitatif. Data kualitatif meliputi semua tanggapan validator dan siswa dengan menggunakan angket. Data kuantitatif meliputi hasil perhitungan nilai rata-rata angket dengan menggunakan Skala Likert yang diberikan pada para ahli dan siswa.

\section{Analisis Data dan Hasil Kevalidan Produk}

Hasil data penilaian modul diperoleh dari para ahli materi, modul dan praktisi diolah menggunakan teknik analisis deskrisptif dalam bentuk persentase. Rumus dijabarkan sebagai berikut.

$$
\text { Persentase }(\%)=\frac{\Sigma x}{E X i} \times 100 \%
$$

$$
\begin{aligned}
& \text { Keterangan: } \\
& \mathrm{P} \quad=\text { Persentase } \\
& \Sigma \mathrm{X}=\text { Total jumlah skor jawaban responden } \\
& \Sigma \mathrm{Xi}=\text { Total jumlah skor ideal }
\end{aligned}
$$

Untuk menarik kesimpulan kevalidan modul, maka hasil hitungan persentase sesuai kriteria validitas oleh Akbar (2013), yaitu rentang persentase antara $85.01-100 \%$ artinya produk dinilai baik dan dapat disebarkan (sedikit revisi), 70.0 - 85.00\% artinya produk baik dan dapat disebarkan (perlu revisi), 50,01—70.00\% artinya cukup baik digunakan (revisi banyak), dan $01.00-$ 
$50.00 \%$ artinya tidak boleh digunakan (harus banyak revisi). Hasil analisis data pengembangan modul oleh validator materi memperoleh rerata persentase sebesar $89,13 \%$ dengan kriteria sangat valid digunakan, setelah produk yang dikembangkan melalui revisi sesuai masukan dari validator. Ringkasan data dari hasil validator ahli materi disajikan pada tabel 1 . Berdasarkan angket yang telah diberikan kepada ahli materi pada saat validasi, diperoleh komentar dan saran yang disajikan pada tabel 2.

Tabel 1. Ringkasan Data Hasil Validasi Modul oleh Ahli Materi

\begin{tabular}{lcc}
\hline \multicolumn{1}{c}{ Indikator Penilaian } & Persentase Penilaian (\%) & \multicolumn{1}{c}{ Keterangan } \\
\hline Kesesuaian materi dengan KD & $100 \%$ & Sangat valid digunakan \\
Keakuratan materi & $80.76 \%$ & Cukup valid digunakan \\
Kedalaman materi & $75.00 \%$ & Cukup valid digunakan \\
Kekontekstualan materi & $100 \%$ & Sangat valid digunakan \\
Kemutakhiran materi & $91.60 \%$ & Sangat valid digunakan \\
Mendorong keingintahuan & $91.60 \%$ & Sangat valid digunakan \\
Penyajian Materi & $85.00 \%$ & Sangat valid digunakan \\
\hline \multicolumn{1}{c}{ Rata-rata } & $89.13 \%$ & Sangat valid digunakan \\
\hline
\end{tabular}

Tabel 2. Revisi Produk dari Ahli Materi

\begin{tabular}{|c|c|c|}
\hline No & Saran Perbaikan & Revisi yang dilakukan \\
\hline 1 & Referensi yang digunakan dalam penyusunan modul harus valid & $\begin{array}{l}\text { Memperbaiki referensi yang disajikan pada modul menggunakan } \\
\text { sumber yang valid }\end{array}$ \\
\hline 2 & $\begin{array}{l}\text { Menampilkan link alamat video untuk proses transkripsi dan } \\
\text { translasi }\end{array}$ & $\begin{array}{l}\text { Menambahkan link alamat video untuk materi proses transkripsi } \\
\text { dan translasi }\end{array}$ \\
\hline 3 & Penulisan kalimat Hukum Mendel I kurang tepat & Memperbaiki kalimat Hukum Mendel I menjadi Hukum I Mendel \\
\hline 4 & $\begin{array}{l}\text { Konsistensi istilah yang digunakan dalam materi modul lebih } \\
\text { diperhatikan }\end{array}$ & $\begin{array}{l}\text { Memperbaiki dan menyelaraskan konsistensi istilah pada materi di } \\
\text { dalam modul }\end{array}$ \\
\hline 5 & Soal evaluasi di Modul terintegrasi ciri soal HOTS & $\begin{array}{l}\text { Memperbaiki soal evaluasi yang terintegrasi dengan ciri soal } \\
\text { HOTS }\end{array}$ \\
\hline
\end{tabular}

Produk berupa modul oleh ahli bahan ajar memperoleh rerata persentase 96,78\% dengan kriteria sangat valid. Ringkasan data dari hasil validator ahli bahan ajar disajikan pada tabel 3. Berdasarkan angket yang telah diberikan kepada ahli bahan ajar pada saat validasi, diperoleh komentar dan saran yang disajikan pada tabel 4. Penilaian yang diberikan oleh praktisi lapangan dari hasil penggunaan modul yaitu rerata persentase $91,75 \%$ dengan kriteria sangat valid dan melakukan revisi sesuai masukan dari praktisi lapangan. Ringkasan data dari hasil validator praktisi disajikan pada tabel 5. Berdasarkan angket yang telah diberikan kepada praktisi lapangan pada saat validasi, diperoleh komentar dan saran yang disajikan pada tabel 6.

Tabel 3. Ringkasan Data Hasil Validasi Modul oleh Ahli Bahan Ajar

\begin{tabular}{lcc}
\hline Indikator Penilaian & Persentase Penilaian (\%) & Keterangan \\
\hline Self instruction & $96,42 \%$ & Sangat valid digunakan \\
Self contained & $87,5 \%$ & Sangat valid digunakan \\
Stand alone & $100 \%$ & Sangat valid digunakan \\
Adaptif & $100 \%$ & Sangat valid digunakan \\
User Friendly & $100 \%$ & Sangat valid digunakan \\
\multicolumn{1}{c}{ Rata-rata } & $\mathbf{9 6 . 7 8}$ & Sangat valid digunakan \\
\hline
\end{tabular}

Tabel 4. Revisi Produk dari Ahli Bahan Ajar

\begin{tabular}{|c|c|c|}
\hline No & Saran Perbaikan & Revisi yang dilakukan \\
\hline 1 & $\begin{array}{l}\text { Halaman pada penyusunan modul lebih baik dibuat menjadi } \\
\text { halaman bolak-balik agar menjadi praktis dan tidak terlihat tebal }\end{array}$ & $\begin{array}{l}\text { Memperbaiki pencetakan modul menjadi halaman yang bolak } \\
\text { balik }\end{array}$ \\
\hline 2 & $\begin{array}{l}\text { Pada proses pencetakan modul lebih baik menggunakan kertas art } \\
\text { paper supaya tulisan dan gambar didalam modul menjadi jelas }\end{array}$ & $\begin{array}{l}\text { Memperbaiki pencetakan modul dengan menggunakan kertas } \\
\text { art paper }\end{array}$ \\
\hline 3 & Jika terdapat punggung buku, maka disana terdapat identitas & Memperbaiki dan menambahkan identitas pada punggung buku \\
\hline 4 & Halaman belakang modul tidak boleh dibiarkan kosong & Menambahkan biodata penulis pada halaman belakang modul \\
\hline
\end{tabular}


Tabel 5. Ringkasan Data Hasil Validasi Modul oleh Praktisi Lapangan

\begin{tabular}{lcc}
\hline Indikator penilaian & Persentase penilaian (\%) & Keterangan \\
\hline Kelengkapan isi & $77.08 \%$ & Cukup valid digunakan \\
Keakuratan materi & $100 \%$ & Sangat valid digunakan \\
Bahasa & $100 \%$ & Sangat valid digunakan \\
Penyajian & $75 \%$ & Cukup valid digunakan \\
\multicolumn{1}{c}{ Rata-rata } & $88,02 \%$ & Sangat valid digunakan \\
\hline
\end{tabular}

Tabel 6. Revsi Produk dari Praktisi Lapangan

Saran Perbaikan

Revisi yang dilakukan

1 Indikator capaian pembelajaran disesuaikan dengan KD $\quad$ Memperbaiki indikator capaian pembelajaran sesuai dengan KD

2 Modul lebih tepat digunakan untuk pembelajaran bagi siswa SMA Modul yang disusun memang ditujukan bagi siswa SMK

\section{Analisis Data dan Hasil Kepraktisan Produk}

Hasil data oleh angket respon siswa melalui uji kepraktisan dioleh dengan menggunakan teknik analisis deskrisptif dalam bentuk persentase. Rumus dijabarkan sebagai berikut.

$$
\text { Persentase }(\%)=\frac{\Sigma \mathrm{X}}{E X i} \times 100 \%
$$

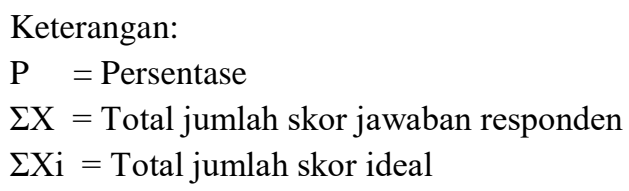

Untuk menarik kesimpulan kepraktisan modul, maka hasil hitungan persentase dirujuk sesuai kriteria validitas oleh Akbar (2013), yaitu rentang persentase antara 81.00 - 100\% artinya sangat praktis dapat disebarkan, 61.00 — 80.00\% artinya praktis dan dapat disebarkan (sedikit revisi), $41.00-60.00 \%$ artinya kurang praktis (banyak revisi), dan $21.00-40.00 \%$ artinya tidak praktis (harus revisi banyak).

Modul yang telah divalidasi oleh ahli bahan ajar dan praktisi lapangan selanjutnya dilakukan uji keterbacaan pada siswa kelas X ATPH 3 di SMKN 1 Tulungagung. Data terkait uji keterbacaan siswa terhadap bahan ajar berupa modul digunakan untuk menilai kepraktisan modul yang digunakan dalam pembelajaran. Hasil uji keterbacaan dari angket respon siswa sejumlah 30 responden menunjukkan persentase rata-rata sebesar $86.87 \%$ dengan kriteria sangat praktis dan selengkapnya dapat dilihat pada tabel 7.

Tabel 7. Ringkasan Data Hasil Uji Keterbacaan Modul oleh Siswa

\begin{tabular}{llcc}
\hline No. & \multicolumn{1}{c}{ Aspek yang dinilai } & Rata-rata (\%) & Keterangan \\
\hline 1. & Kemenarikan modul & 84.84 & Sangat Praktis \\
2. & Kemudahan modul untuk digunakan & 86.81 & Sangat Praktis \\
3. & Kemudahan modul untuk dipahami & 88.96 & Sangat Praktis \\
& $\quad$ Rata-rata nilai & 86.87 & Sangat Praktis \\
\hline
\end{tabular}

\section{PEMBAHASAN}

Pemuliaan tanaman dapat dilakukan melalui kegiatan persilangan buatan antar individu yang memiliki sifat berbeda (Arsyad, Adie, \& Kuswantoro, 2007); (Lubis, Rosmayanti, \& Hanafiah, 2015). Kegiatan pemuliaan tanaman mampu menghasilkan varietas, klon, dan galur baru yang mempunyai sifat atau karakter lebih unggul dibanding tetuanya (Nasir, 2001), melalui manipulasi genetik dua tetua guna memperoleh perbaikan permanen pada turunannya (Acquaah, 2012). Seleksi dalam memilih genotipe kedelai unggul menggunakan karakterisasi agronomi, morfologi, dan anatomi serta kemampuan adaptasi terhadap lingkungan sebagai kriteria (Ningsih, F., Zubaidah, S., \& Kuswantoro, H., 2017). Selain itu seleksi parameter genetik yang efektif diantaranya besaran nilai keragaman genetik, pola segregasi, heritabilitas, aksi gen, jumlah gen, dan heterosis (Barmawi, 2007; Sayurandi \& Aidi-daslin, 2011; Syukur, M., S. Sujiprihati., R. Yunianti., \& D. A. Kusumah, 2011).

Fenomena Heterosis merupakan fenomena peningkatan sifat dibandingkan dengan sifat terbaik induknya (Welsh, 1991). Nilai heterosis positif mengindikasikan persilangan kedua tetua memperoleh keturunan yang sifatnya lebih unggul dari tetua tertinggi (Aryana, 2010), sedangkan nilai heterosis negatif mengindikasikan perlu kombinasi persilangan yang banyak untuk mengidentifikasi kombinasi persilangan heterosis terbaik (Perez, P.T., S.R. Cianzio, and R.G. Palmer, 2009). Hasil penelitian 
mengenai karakterisasi heterosis morfologi, anatomi, dan agronomi kedelai dapat digunakan sebagai sumber penyusunan bahan ajar Biologi untuk SMK Pertanian pada KD 3.11 dan 4.9 topik Pewarisan Sifat.

Hasil penelitian berupa pengembangan produk dinilai oleh ahli modul, praktisi, dan materi. Hasil analisis data pengembangan modul oleh validator materi memperoleh rerata persentase $89,13 \%$ dengan kriteria sangat valid digunakan, setelah produk yang dikembangkan melalui revisi sesuai masukan dari validator. Produk berupa modul oleh ahli bahan ajar memperoleh rerata persentase $96,78 \%$ dengan kriteria sangat valid digunakan dalam pembelajaran dan melakukan revisi sesuai masukan dari validator. Penilaian yang diberikan oleh praktisi lapangan yaitu guru pengampu mata pelajaran Biologi di SMKN 1 Tulungagung diperoleh hasil penggunaan modul dengan rerata persentase 91,75\% dengan kriteria sangat valid dan melakukan revisi sesuai masukan dari praktisi lapangan. Hasil penilaian validator ahli modul, materi dan praktisi lapangan membuktikkan bahwa keseluruhan aspek kriteria penilaian tersebut telah terpenuhi sangat baik dan produk yang dikembangkan sangat baik digunakan dalam kegiatan pembelajaran. Modul kriteria digunakan pada kegiatan pembelajaran yaitu self contained, user friendly, self instruction, adaptif, dan stand alone ( Direktorat Tenaga Kependidikan, 2008; Depdiknas, 2008). Peran modul mengajak siswa untuk aktif pada pembelajaran sehingga menciptakan suasana belajar yang berpusat pada siswa (Susilo, Siswandi, \& Bandi, 2006).

Hasil dari uji kepraktisan siswa oleh 32 siswa kelas X ATPH 3 di SMKN 1 Tulungagung dilaksanakan pada bulan April. Angket respons siswa memiliki tiga aspek, yaitu aspek kemenarikan modul, kemudahan modul untuk digunakan, dan kemudahan modul untuk dipahami. Secara keseluruhan, hasil angket respons siswa dengan modul yang disusun berdasarkan ketiga aspek diperoleh rerata persentase $86.87 \%$. Disimpulkan bahwa pengembangan modul berbasis PBL pada topik Pewarisan Sifat dinyatakan sangat praktis. Motivasi belajar siswa menjadi meningkat ketika menggunakan modul berbasis PBL, karena menambah informasi menarik dan materi didalamnya mudah dipahami (Sukiman, 2012; Gustinasari, Lufri, \& Ardi, 2017). Modul yang dikembangkan meskipun digolongkan dalam kriteria valid dan praktis, namun terdapat beberapa catatan dan masukan yang difungsikan untuk revisi modul. Perlu dilakukan implementasi modul dalam pembelajaran siswa di kelas, agar dapat membuktikan bahwa modul benar-benar efektif untuk meningkatkan hasil belajar siswa dibandingkan dengan tanpa modul.

\section{Revisi Produk}

Adapun perbaikan produk berdasarkan masukan dan saran validator, meliputi (1) referensi yang digunakan dalam penyusunan modul harus valid, (2) penggunaan konsistensi kata dalam materi modul lebih diperhatikan, (3) menampilkan link alamat video untuk proses transkripsi dan translasi (4) halaman pada penyusunan modul lebih baik dibuat menjadi halaman bolakbalik agar menjadi praktis dan tidak terlihat tebal, (5) jika terdapat punggung buku, maka disana terdapat identitas, (6) pada proses pencetakan modul lebih baik menggunakan kertas art paper supaya tulisan dan gambar didalam modul menjadi jelas, dan (7) indikator capaian pembelajaran disesuaikan dengan KD. Secara keseluruhan, hasil revisi produk dijabarkan pada gambar $1-5$. 


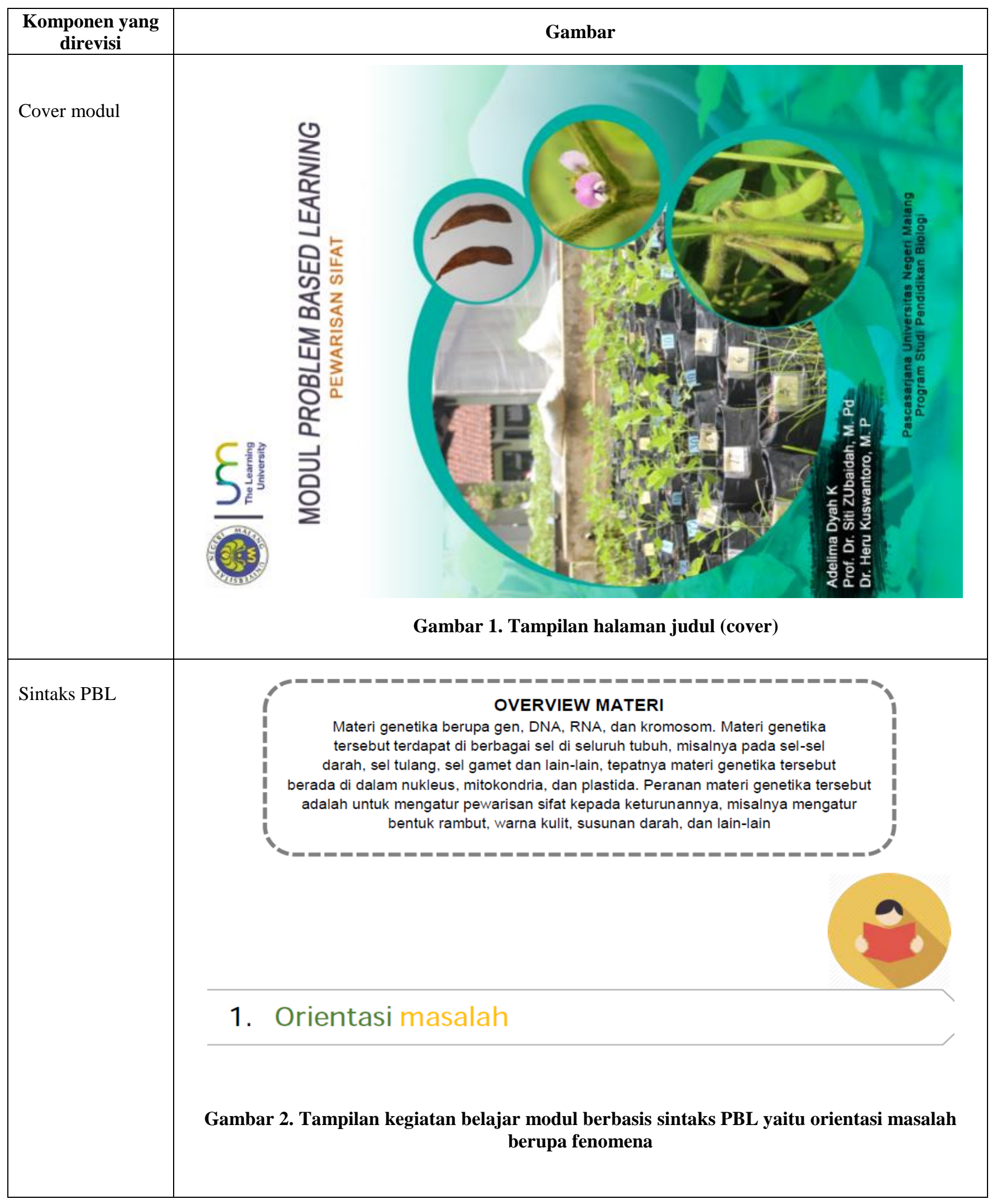


Sintaks PBL

Sintaks PBL

Gambar 3. Tampilan kegiatan belajar siswa berbasis sintaks PBL yaitu membantu investigasi

Kegiatan Penyelidikan I. Mengamati sifat fenotipe dari beberapa varietas tanaman kedelai untuk masing-masing sifat guna mengetahui peran gen dalam suatu mahkluk hidup.

Peneliti menggunakan kedelai dalam penelitiannya sebab memiliki sifat penting. Apakah Saudara/i telah benar melihat beberapa sifat tersebut pada tanaman kedelai? Agar lebih yakin tentang beberapa sifat tersebut, carilah kedelai yang memiliki sifat -sifat tersebut. Kemudian ambil gambar/foto untuk masing-masing sifat dan buatlah laporan pada kolom jawaban yang sudah disediakan. Diskusikanlah fenomena yang mencerminkan peran gen dalam mempengaruhi sifat yang tampak pada tanaman kedelai tersebut!

1. Setelah kalian memperhatikan fenomena berupa fakta di tahap orientasi masalah, kini saatnya merancang kegiatan yang akan kalian lakukan untuk menjawab rumusan dan solusi dari rumusan masalah yang telah kalian buat!

2. Catatlah hasil kegiatan diskusi kelompok kalian pada kolom jawaban yang sudah disediakan!

3. Carilah referensi atau sumber belajar yang relevan untuk memudahkan kalian menjawab pertanyaan tersebut

\section{secara mandiri dan kelompok}

3. Membantu investigasi secara mandiri dan kelompok 


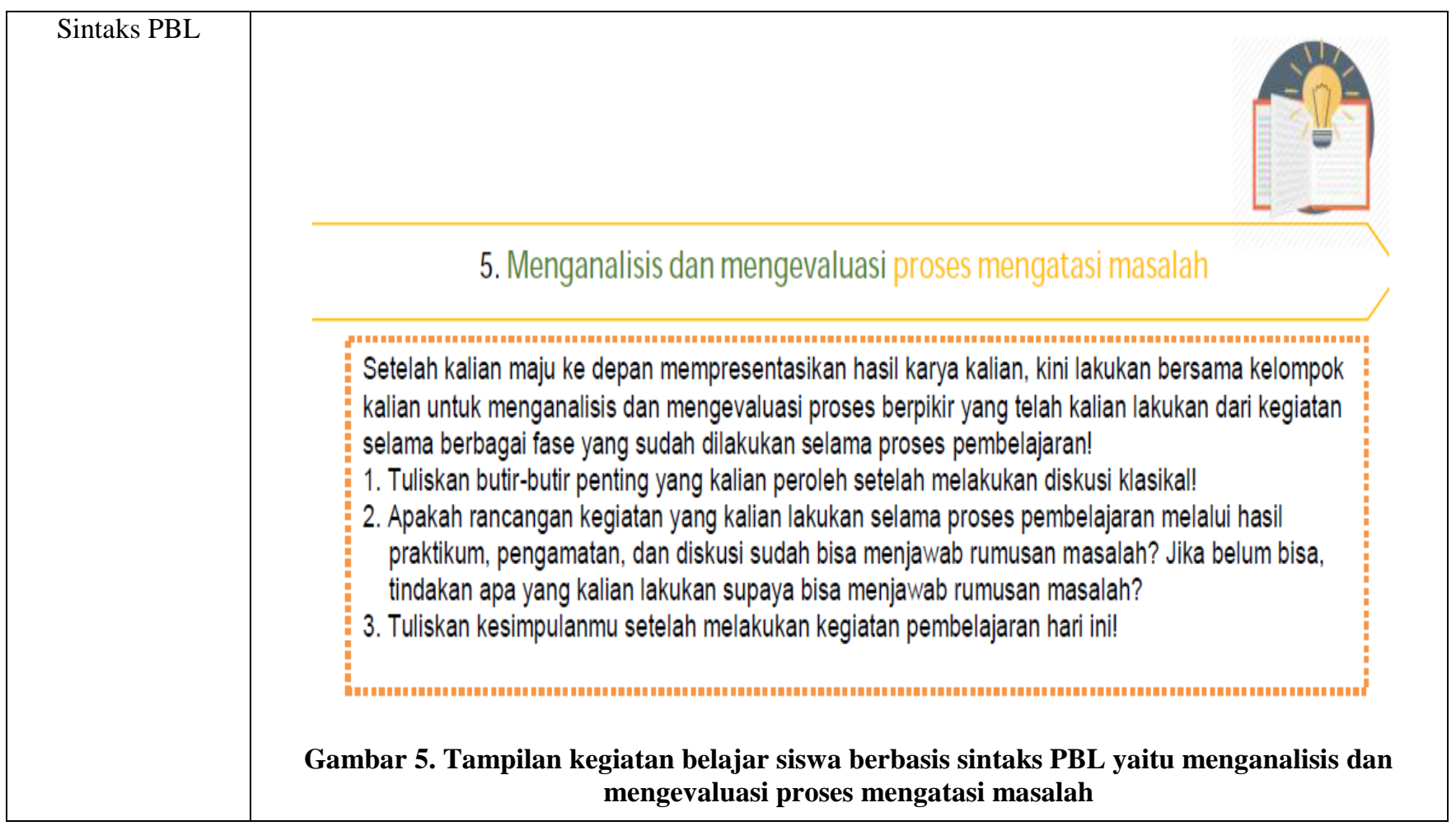

\section{SIMPULAN}

Secara keseluruhan, hasil validasi modul dinilai oleh praktisi lapangan, ahli modul, dan ahli materi sesuai dengan aspek yang telah dinilai memperoleh persentase yang baik. Praktisi lapangan memperoleh rerata persentase sebesar 91,75\%, validasi ahli modul memperoleh rerata persentase sebesar $96,78 \%$ dan validasi ahli materi memperoleh rerata persentase sebesar $89,13 \%$. Hasil ini disimpulkan bahwa pengembangan modul Problem Based Learning pada topik Pewarisan Sifat memperoleh kriteria sangat valid. Secara keseluruhan, hasil angket respons siswa terhadap modul Problem Based Learning berdasarkan ketiga aspek diperoleh rerata persentase sebesar 86.87\%. Disimpulkan bahwa pengembangan modul berbasis Problem Based Learning pada topik Pewarisan Sifat dinyatakan sangat praktis. Penelitian pengembangan ini perlu uji coba keefektifan guna mengetahui modul yang dikembangkan efektif atau tidak pada topik Pewarisan Sifat.

\section{DAFTAR RUJUKAN}

Agustina, P., Muhdhar, M. H. I. Al, \& Amin, M. (2014). Pengembangan Modul Inkuiri Berorientasi Life Skills pada Materi Pencemaran Lingkungan untuk Siswa Kelas X Sekolah Menengah Atas (SMA). Prosiding Seminar Biologi, 11(1), 871879.

Aidi-Daslin., \& Sayurandi. (2011). Heterosis dan Heritabilitas pada Progeni F1 Hasil Persilangan Kekerabatan Jauh Tanaman Karet. Jurnal Penelitian Karet, 29(1), 1-15.

Alfiantara, A., Kusumo, E., \& Susilaningsih, E. (2016). Pengembangan Modul Berorientasi Problem Based Learning. Jurnal Inovasi Pendidikan Kimia, 10(2), 1769-1777.

Arends. (2008). Learning to Teach. Pustaka Pelajar.

Arsyad, D. M., Adie, M. M. M., \& Kuswantoro, H. (2007). Perakitan Varietas Unggul Kedelai Spesifik Agroekologi. KedelaiTeknik Produksi dan Pengembangan, 205-228.

Aryana. (2010). Uji Keseragaman, Heritabilitas, dan Kemajuan Genetik Galur Padi Beras Merah Hasil Seleksi Silang Balik di Lingkungan Gogo. Crop Agro: Jurnal Ilmiah Budidaya Pertanian, 3(1), 10-17.

Barmawi, M. (2007). Pola Segregasi dan Heritabilitas Sifat Ketahanan Kedelai terhadap Cowpea Mild Mottle Virus Populasi Wilis X MLG2521 252 Jurnal Hama dan Penyakit Tumbuhan Tropika, 7(1), 48-52.

Belt, S., Evans, E., McCreedy, T., Overton,T. \& Summerfield, S. (2002). A Problem Based Learning Approach to Analytical and Applied Chemistry. University Chemistry Education, 6, 65-72.

Boud. (1985). Problem-Based Learning in Perspective. In : Boud, D. (ed). Problem-Based Learning in Education for the Professions. Sydney: HERDSA. 
Branch. (2009). Instructional Design: The ADDIE Approach. London: Springer New York Dordecht Heidelberg.

Depdiknas. (2008). Perangkat Pembelajaran SMA. Jakarta: Departemen Pendidikan Nasional Direktorat Jenderal Managemen Pendidikan Dasar Dan Menengah Direktorat Pembinaan Sekolah Menengah Atas

Gustinasari, M., Lufri., \& Ardi. (2017). Pengembangan Modul Pembelajaran Berbasis Konsep Disertai Contoh pada Materi Sel untuk Siswa SMA. Bioeducation Journal, 1(1), 60-73.

Krisanti, E. \& Mulia, K. (2016.). Penerapan Metode Problem-Based Learning (PBL). Leutika Nouvalitera.

Kusumaningtias, B., Zubaidah, S., \& Indriwati, S.E. (2013). Pengaruh Problem Based Learning Dipadu Strategi Numbered Heads Together Terhadap Kemampuan Metakognitif, Berpikir Kritis, dan Kognitif Biologi. Jurnal Penelitian Pendidikan Tahun, 23(1), 33-47.

Lestari, I. (2013). Pengembangan Bahan Ajar Berbasis Kompetensi Sesuai dengan Kurikulum Tingkat Satuan Pendidikan. Jakarta: Akademia Permata.

Loyens, S. M. M., \& Paas, F. (2011). Problem-based learning. In K. R. Harris, S. Graham \& T. Urdan (Eds.), APA Educational Psychology Handbook: Vol 2 (p. a). Washington: American Psychological Association.

Lubis, N. A., Rosmayanti, \& Hanafiah, D. S. (2015). Persilangan Genotipe-Genotipe Kedelai (Glycine max L. Merrill.) Hasil Seleksi pada Tanah Salin dengan Tetua Betina Varietas Grobogan. Jurnal Online Agroekoteknologi, 3(2337-6597), 291298.

Majid. (2007). Perencanaan Pembelajaran. Bandung: PT. Remaja Rosdakarya.

Makmun. (2005). Psikologi Kependidikan Perangkat Sistem Pengajaran Modul. Bandung: Remaja Rosdakarya

Mayo, P., Donnelly, M.B., Nash, P.P. \& Schwartz, R.W. (1993). Student Perceptions of Tutor Effectiveness in a Problem-Based Surgery Clerkship. Teaching and Learning in Medicine: An International Journal, 5, 227-233.

Nasir. (2001). Pengantar Pemuliaan Tanaman. Jakarta: Departemen Pendidikan Nasional

Ningsih, F., Zubaidah, S., \& Kuswantoro, H. (2017). Karakteristik Agronomi Plasma Nutfah Kedelai (Glycine max L. Merill). Pros. Seminar Pendidikan IPA Pascasarjana UM, 2, 437-444.

Pranata, B. D., Mahanal, S., Lestari, U. (2016). Pengembangan Modul Pembelajaran Biologi Berbasis Discovery Inquiry pada Materi Sistem Reproduksi untuk Siswa Kelas XI SMA. Tesis tidak diterbitkan. Universitas Negeri Malang, Malang.

Primarinda, I., Prayitono, A, B., \& Maridi. (2015). Pengembangan Modul Berorientasi Problem Based Learning pada Materi Pencemaran untuk Memberdayakan Kemampuan Berpikir Kritis dan Sikap Peduli Lingkungan Siswa SMA Negeri 1 Karanganyar. Tesis tidak diterbitkan. Universitas Sebelas Maret, Surakarta.

Sadjati. (2004). Pengembangan Bahan Ajar. Jakarta: Universitas Terbuka.

Sukiman. (2012). Pengembangan Media Pembelajaran. Pedagogia.

Susanti. (2015). Pengembangan Modul Pendidikan Lingkungan Hidup dengan Pendekatan Sains Lingkungan Teknologi dan Masyarakat sebagai Upaya dalam Mengembangkan Sikap Peduli Lingkungan. Tesis tidak diterbitkan. Universitas Negeri Malang, Malang.

Susilo.A., Siswandari., \& Bandi. (2014). Pengembangan Modul Berbasis Pembelajaran Saintifik untuk Meningkatkan Kemampuan Mencipta Siswa Dalam Proses Pembelajaran Akuntasi Siswa Kelas XII SMA. Jurnal Pendidikan Ilmu Sosial., 26(1).

Syukur, M., S. Sujiprihati., R. Yunianti., \& D. A. Kusumah. (2011). Pendugaan Ragam Genetik dan Heritabilitas Karakter Komponen Hasil Beberapa Genotipe Cabai. Journal Agrivigor Indonesia, 10(2), 148-156.

Welsh. (1991). Dasar-Dasar Genetika dan Pemuliaan Tanaman. Terjemahan Johanes P. Mogea. Erlangga, Jakarta.

Welty. (2007). The 'Design' Phase of The ADDIE Model. Journal of GXP Compliance, 12(4), 40-48.

Whitcombe. (2013). Problem-Based Learning Student's Perceptions of Knowledge and Profesional Identity: Occupational Therapists as 'Kowers'. British Journal of Occupational Therapy, 76(1), 37-42.

Yuan, H., Kunaviktikul, W., Klunklin, A. \& Williams, B.A. (2008). Promoting Critical Thinking Skills Through Problem Based Learning, 2(2), 85-100. 